This article was downloaded by: [University of Stockholm]

On: 29 November 2010

Access details: Access Details: [subscription number 918420983]

Publisher Routledge

Informa Ltd Registered in England and Wales Registered Number: 1072954 Registered office: Mortimer House, 3741 Mortimer Street, London W1T 3JH, UK

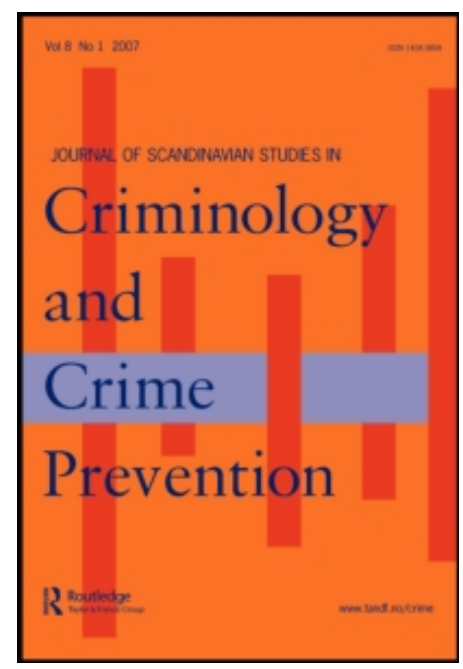

Journal of Scandinavian Studies in Criminology and Crime Prevention

Publication details, including instructions for authors and subscription information:

http://www.informaworld.com/smpp/title content=t713690200

\title{
Violence at Work-The Emergence of a Social Problem
}

Felipe Estrada ${ }^{\text {a }}$ : Anders Nilsson ${ }^{\text {a }}$ Kristina Jerre ${ }^{\text {a }}$, Sofia Wikman ${ }^{\mathrm{a}}$

${ }^{a}$ Department of Criminology, Stockholm University and Institute for Futures Studies, Sweden

Online publication date: 29 April 2010

To cite this Article Estrada, Felipe, Nilsson, Anders, Jerre, Kristina and Wikman, Sofia(2010) 'Violence at Work-The Emergence of a Social Problem', Journal of Scandinavian Studies in Criminology and Crime Prevention, 11: 1, 46 - 65 To link to this Article: DOI: $10.1080 / 14043851003703846$

URL: http://dx.doi.org/10.1080/14043851003703846

\section{PLEASE SCROLL DOWN FOR ARTICLE}

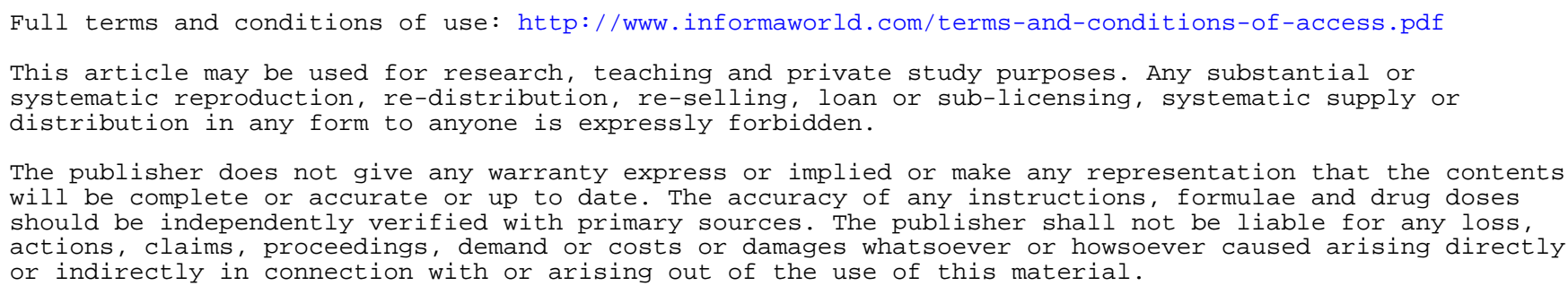




\section{Violence at Work-The Emergence of a Social Problem}

FELIPE ESTRADA, ANDERS NILSSON, KRISTINA JERRE, AND SOFIA WIKMAN

Department of Criminology, Stockholm University and Institute for Futures Studies, Sweden

Abstract

This article analyses trends in violence at work on the basis of victim surveys, workenvironment surveys, and press material. It proceeds from the two most common explanations of why violence at work appears to have increased over recent decades. These emphasize shifts in working conditions that have increased employees' victimization risk, and a broadened view of what is regarded as work-related violence. The empirical analyses provide support for both these explanations, and the various dimensions examined-increased reporting propensities, expanded definitions, a reduced tolerance of violence, and altered working conditions-are linked to one another.

KEY WORDS: Crime trends, Social constructionism, Sweden, Victimization, Working conditions
Over the past Io to I 5 years, the attention focused on threats and violence at work has greatly intensified. A variety of European surveys describe this violence as an increasing problem (Flannery I996; Chappell and Di Martino 2006; Balvig and Kyvsgaard 2006; EWCO 2007; Heiskanen 2007). In many countries, this increase represents a deviation from more stable trends in other kinds of violence (see e.g. Balvig and Kyvsgaard 2006; Estrada et al. 2007; Heiskanen 2007). One important finding from sociological research is that perceptions and definitions of violence are context-dependent. We also know that the amount of attention society directs at a given social problem affects both how it is perceived and the extent to which it becomes visible in official statistics (e.g. Kitsuse and Cicourel I963; Estrada 200I; Steffensmeier et al. 2005). In order to describe trends in work-related violence it is therefore essential to focus on possible shifts in how incidents are perceivedwhat is regarded as violence and to what extent is it reported? To date, analyses of work-related violence have paid little attention to these factors. This article summarizes the findings from the first three studies of our research project on work-related violence as a social problem (Estrada et al. 2007; Wikman 2008; Jerre 2009).

The central question is that of how we should understand the fact that an increasing number of employees are reporting being exposed to violence. To what extent does this reflect a shift in perceptions of violence and/or an increase in the level of victimization? Since these are complex questions, we approach them using different data sources and analytical methods.

- Firstly, we analyse the trend over time on the basis of victim surveys, focusing on both the proportion exposed to violence and the nature of this exposure.

- Secondly, we study whether the risks for violence associated with the work environment have changed. Can trends in threats and violence at work be linked to changes in the work environment? 
- Thirdly, on the basis of a content analysis of occupational journals' descriptions of violence at work, we describe how perceptions of and the attention focused on this problem have changed over time.

The project proceeds from a contextual constructivist perspective (Best I993, I995; Lindgren 2005). Stated briefly, contextual constructivism involves analysing the extent of and trends in social problems whilst at the same time explicitly focusing on how social problems are constructed, maintained, and legitimized. These latter aspects are important, since representatives of a more objectivist approach sometimes acknowledge the significance of subjective aspects of social problems without then focusing very much on this in their research. And this is a problem, since we know from research on the emergence of social problems that perceptions of a problem are significant for the counter-measures that are deemed reasonable and effective (Blumer I97I). In the final analysis, the counter-measures employed are dependent on an adequate description of trends in work-related violence, on how the problem is defined, and on its consequences as perceived by the victims. The goal of the current project is therefore to integrate the objectivist emphasis on the concrete nature of social problems with the valuable constructivist insight that the status of a social problem is not exclusively determined by its objective character.

\section{Two explanations for the increase}

Several scholars argue that violence has become an increasingly high-profile social problem and that the increased attention focused on, and sensitivity to, violence is reflected in increases in officially registered violence, while alternative sources indicate unchanged levels of violent crime (cf. Estrada 200I, 2006; Steffensmeier et al. 2005). Christiansen (2005), Balvig and Kyvsgaard (2006), and Kruize et al. (2008) have analysed work-related violence in Denmark, with results that support such an interpretation. One hypothesis is thus that the attitudes of various occupational groups have shifted in line with the increased attention focused on violence in society at large, resulting in a new pattern of violence-reporting behaviour.

An alternative explanation is that changes have occurred in the work environment that affect employees' risks for exposure to violence. Engelstad (2003) argues, for example, that work-related factors such as increased decentralization and staffing cut-backs, as well as the closure of amongst other things large health care institutions, have led to an increased risk for violence at work. Bäckman (200I) shows that those working in the health care, school, and welfare sectors experienced a marked deterioration in particularly their psycho-social working conditions during the I 990 os by comparison with other groups. To understand trends in violence it is therefore important not only to identify conditions at work that increase the risk for threats and violence, but also to analyse how employees' exposure to these conditions has developed over time.

Against this background, it is not clear how the increase in work-related violence should be understood. It is unclear to what extent the increase reflects an increase in the number of victims, e.g. as a result of altered working conditions, and/or increased attention and an expanded definition of what constitutes violence. 
Our hope is that the three sub-studies presented in this article will together contribute to an improved understanding of the emergence of work-related violence as a social problem.

\section{Study 1: Increasing work-related violence as reflected in victim surveys}

Knowing whether the character of the problem has changed is central to the issue of how the trend in work-related violence is to be understood. We have the opportunity to study this issue on the basis of victim surveys by looking at I) the seriousness of the violence, 2) which occupational groups are victimized, and 3) to what extent the victims have contacted the police. Have there been changes? And, if so, what is their significance for our interpretation of victimization trends?

\section{The data}

The Swedish level-of-living surveys (ULF) have been conducted annually since 1978 (described in more detail in e.g. Nilsson and Estrada 2003). The ULF data are based on personal interviews with a representative sample of the population (nonresponse approximately $20 \%$ ). This study primarily employs data from the I984/I985, I992/I993, and 2000/200I surveys, since these were years when the survey included extra follow-up questions on exposure to crime. We have restricted ourselves to individuals aged between 20 and 64 who were in employment at the time of the interview. This gives us a total sample size of 22,507 individuals. As regards to experiences of violence, the ULF surveys include four key questions relating to differing degrees of violence. The first refers to the most serious forms of violence and reads: 'During the last
I 2 months, have you personally been the victim of a violent act or acts that have led to injuries requiring you to visit a doctor, dentist, or nurse?' The respondent is then asked about violence which caused visible marks or physical injury, violence that did not lead to visible marks or physical injury, and whether he or she has been threatened with violence in such a way as to be frightened. The respondents are also asked where these incidents have taken place, distinguishing between six principal alternatives, the work-place being one of them. Reporting propensity is measured by the question ' $\mathrm{Did}$ you contact the police at all?'.

\section{Trends in victimization for men and women}

Figure I presents trends in men's and women's exposure to any threats or violence and to work-related violence respectively during the period I9782004. It is clear that the level of victimization is significantly higher among men than among women. This is not the case, however, in the final three years of the period examined. The explanation is largely found in the trend in work-related violence. Until the beginning of the r980s, men and women reported similar levels of exposure to work-related violence. Thereafter, however, women's victimization increased whilst that of men remained stable.

Table I shows that it is trends in violence and not threats that account for the increasing difference between men and women (note that by comparison with Figure I, the table only includes those of working age who are in employment). Exposure to threats is significantly higher in $2000 / 0 \mathrm{I}$ than in $1984 / 85$ for both men 


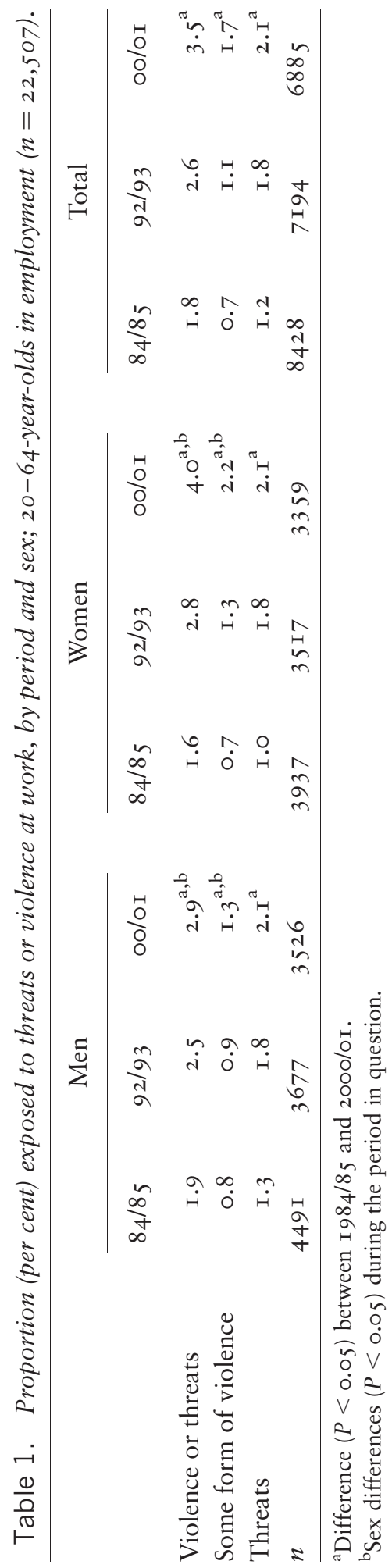

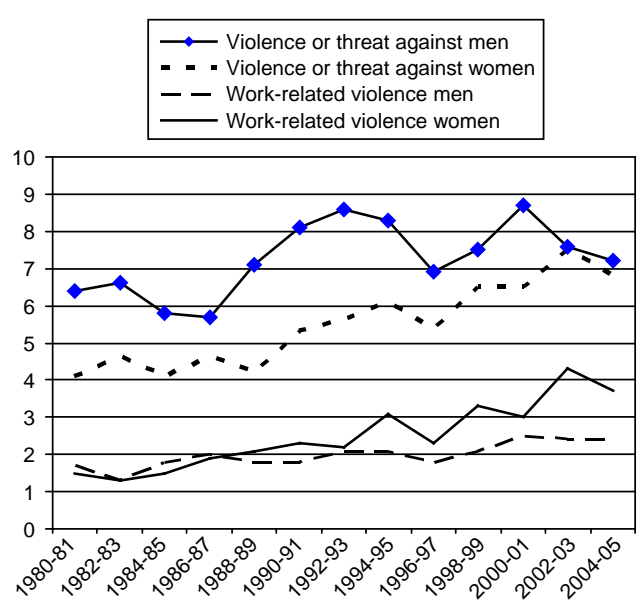

Figure 1. Proportions (per cent) exposed to any violence or threats (16-84 year-olds) or workrelated violence respectively (16-64 year-olds), 1980-2005. Men and women.

and women, but lies at roughly the same level as it did in $1992 / 93$. Exposure to some form of physical violence has by contrast increased among both men and women since the beginning of the I99os. For the women, there has been a relatively dramatic increase since the mid-r980s. This trend is found both for more and less serious forms of physical violence (not presented in the table).

\section{Trends in victimization in different occupational groups}

Possible changes in the character of violence may be reflected in the nature of the occupational groups that are victimized. We have divided those in employment into five different sector groups: school, retail, health care, social services, and security services. The remaining occupations form a comparison group labelled 'other occupations'. Of those exposed to work-related violence or threats, $55 \%$ are drawn from the five occupational groups named, while these 
groups account for $27 \%$ of those in employment. Figure 2 shows that the occupational groups are associated with different trends over the period I984200I. Employees in the health care, social services, and school sectors are those who have experienced a significant increase in levels of victimization.

Women comprise a large proportion of those working in the groups school, retail, bealth care, and social work $(73 \%-92 \%)$, while men dominate the categories security $(84 \%)$ and other $(6 \mathrm{I} \%)$. It is interesting to note that the significant increases are found within the welfare service occupations in the public sector, but not in the similarly woman-dominated occupational category retail. Thus the increase occurs in precisely those groups that experienced worse trends than others in their working conditions during the I990s (Bäckman 200I).

One interesting question is that of whether men working in health and welfare occupations present the same trends and levels of exposure as the

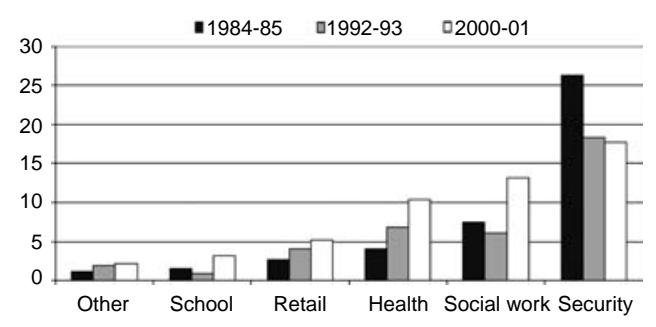

Figure 2. Proportion (per cent) exposed to workrelated violence or threats in different occupational groups 1984/85, 1992/93, and 2000/01. Note: Changes between the periods have been tested for significance using the chisquare statistic. The increases between the years 1992/93 and 2000/01 are significant among employees in the school, health care, and social work sectors. Changes are not statistically significant for the other occupational groups. women. Since the proportion of men in these occupations is low, conducting separate analyses for the sexes over time is associated with uncertainties. In our material, however, no major differences are visible in the trends experienced by the men and women working in these occupational groups (data not presented). Looking to the material as a whole, men working in health care, the social services, and security present a somewhat higher level of victimization than their female counterparts. By contrast, no differences between the sexes were found among those employed in retail, schools, and other occupations (see also Study 2 below).

\section{Reporting propensities}

Only a small fraction of all violent incidents are perceived as intentional criminal acts. This becomes very clear in the area of work-related violence, because several of the most exposed occupational groups perceive these violent incidents as an everyday part of the occupational role. The relationship between victim and 'perpetrator' also differs markedly between employees working in the school, health care and welfare sectors and other occupational groups. In the welfare professions, victims are likely to interpret such situations as crimes less often. This makes it less likely that the individual concerned will contact the police or even mention the event as an incident of exposure to violence in the context of a victim survey.

The proportion who have contacted the police as a result of exposure to threats or violence at work declines markedly between $1984 / 85$ and $1992 / 93$ (Table 2). At the same time, however, the trend shows more individuals being victimized. 
Table 2. Proportion (per cent) of those exposed to work-related threats or violence during the past 12 months who have contacted the police in connection with an incident of this kind (20-64-year-olds in employment).

\begin{tabular}{lccr}
\hline & $\mathrm{I} 984 / 85$ & $\mathrm{I992/93}$ & 2000/0I \\
\hline Proportion contacting police & 40 & 28 & 29 \\
$n$ (number victimized) & $\mathrm{I} 49$ & $\mathrm{I} 89$ & 239 \\
\hline
\end{tabular}

For non-work-related violence, the trend is different, with both the proportion being victimized and reporting propensities remaining more stable (not presented in the table, but see Estrada et al. 2007). Thus in relation to violence at work, the propensity to report is higher when the level of victimization is lower and vice versa. How are we to understand this?

One possible explanation lies in the different trends that characterize the different occupational groups. In total, violent incidents against employees in retail occupations led to police contacts substantially more often than those that victimize health care employees (data not presented). Given that employees in the health care, school, and social work sectors present the most marked increases in exposure to threats and violence, it is worth taking a closer look at the reporting propensities of these groups (Table 3). Instead of a decline in the proportion contacting the police, we see an increase at the end of the period examined. It is notable, however, that employees in the welfare professions continue to present markedly lower reporting propensities than other occupational groups. By far the most common reason given by welfare service employees for not reporting their exposure to violence to the police is that they perceive these incidents as part of the job (just over $80 \%$ state this reason).

\section{Conclusion: trends according to victim} surveys

The Swedish victim surveys show that the majority of those who report exposure to work-related violence are now women. This was not the case in the I980s. The fact that increases in exposure are not found across all female-dominated occupations suggests, however, that this trend is primarily linked to the occupational group rather than to gender. Existing research suggests at least two explanations for the increase in violence at work: the combination of an increased propensity to report and an extended definition of

Table 3. Proportion (per cent) of employees in the health care, school, and social work sectors who have been exposed to work-related threats or violence over the past I 2 months and who have contacted the police in connection with an incident of this kind.

\begin{tabular}{lccr}
\hline & I9 $84 / 85$ & I992/93 & 2000/0I \\
\hline Proportion contacting police & I3 & I3 & I9 \\
$n$ (number victimized) & 47 & $6 \mathrm{I}$ & I07 \\
\hline
\end{tabular}


work-related violence, and a deterioration in working conditions.

One finding that is perhaps somewhat surprising is that the reporting propensity associated with work-related violence has diminished somewhat, something that is not true for other types of violence. This trend is conceptualized against the background of a shift in and broadening of the type of incidents reported in the context of victim surveys. The events that have increased occur primarily in the femaledominated welfare services, where traditionally such incidents have rarely been interpreted as violence that should be reported to the police. As these welfare professions come to account for an increasing proportion of violent incidents, then, the overall propensity to report work-related violence would be expected to diminish. When the focus is directed exclusively at victims within the welfare services sector, however, there are no signs that their propensity to report has declined, but rather the opposite appears to be the case. Against this background, our results suggest a shift in the way violence is perceived by employees in the welfare professions.

An alternative explanation is that the increase in victimization might be a result of changes in the work environment. Our first study provides support for such an interpretation to the extent that the increased victimization risk is primarily associated with employees in the welfare sector, precisely the groups whose working conditions deteriorated during the I990s in relation to those of other occupations (Bäckman 200I). At the same time, the increase is already visible prior to this deterioration in working conditions. In summary, the results are not unequivocal.
In the following, we therefore examine changes in working conditions and perceptions and definitions of work-related violence respectively.

\section{Study 2: Increased violence-a consequence of altered working conditions?}

Proceeding from a view that certain working conditions increase the risk for employees' exposure to threats and violence, changes in employees' exposure to such conditions can reasonably be expected to have consequences for trends in experiences of threats and violence. This study contributes to the research by focusing on two important questions. What working conditions increase the risk for employee exposure to threats and violence? And has the proportion of employees exposed to such violence-related conditions changed in a way that can be linked to the increase noted in exposure to work-related threats and violence?

\section{Existing research on violence-related working conditions}

According to Viitasara and Menckel (2002), the risk for threats and violence at work is affected by several factors working at different levels; from structural factors at the organizational level, via situational conditions at the work-place, to individuallevel factors among both victims and perpetrators. The characteristics of an occupation, such as having direct contacts with external, potentially aggressive individuals, or the exercise of control or power over others, constitute clear risk factors (Brink and Mathiesen Bech 2003; Viitasara et al. 2003; Findorff et al. 2004). As a rule, victimization is also greater in the public sector occupations involving contacts with clients and/or patients (EWCO 2007). 
The risk for violent victimization is also greater for those working evenings, nights or shifts, and for those who work alone (Christiansen 2005).

Structural factors in an organization affect psycho-social working conditions, which can in turn create situations that place employees at risk of threats or violence (Viitasara and Menckel 2002). The most widely used model for studying psycho-social working conditions is the 'demand-control model' (Karasek and Theorell I990). According to this model, it is high demands in combination with a lack of opportunities to exercise control that create the negative stress which over time can lead to psychological or physical ill health. Previous studies show that assaults are more common among employees who experience high levels of stress (Hurrell et al. I997; Kop et al. I999). Empathy for clients or patients is inhibited by stress, and when this occurs care provision can be perceived as a violation which increases the risk for confrontations (Christiansen 2005).

The feeling of having little control, in the sense of having few opportunities to affect one's situation, a lack of knowledge, and little experience, is associated with an increased risk of violent victimization at work (Gage and Kingdom I995). High demands in the form of an intense and heavy work-load are linked to an increased risk for violence via the stress caused to employees by the required working tempo. It can also lead to queues and long waiting times for customers and patients, which increase the risk for discontent and conflict from both parties (Poster I996; Mayhew 2000; Menckel and Viitasara 2002). Previous studies have also found correlations between different factors in the physical working environment and exposure to violence. These factors, however, are probably an indirect reflection of other working conditions (further discussed in Jerre 2009).

\section{Data and method}

In Sweden, Statistics Sweden has conducted the Work Environment Survey (AMU) every second year since I989. AMU is an interview survey conducted in part by telephone, in part using postal questionnaires. Each survey wave is based on a sample of IO-I5,000 people aged between I 6 and 64 years. The nonresponse in the AMU has increased from just under $20 \%$ to just under $40 \%$ between I989 and 2005. The non-response is compensated for by a stratification process so that the distribution of sex, occupation, and other demographic factors matches that in the population as a whole. Victims of violence are those who have reported that they have been exposed to threats or violence at work during last I 2 months. Since both the data collection method and the questions employed differ between the AMU and the ULF, levels of victimization cannot be compared between the two. Furthermore, the question on threats and violence was changed in the AMU after I993 in a way that means that the trend can only be described for the period I995-2005. However, our focus is primarily directed at how the working conditions associated with violence have evolved over time, and these indicators can be followed for the period I99I-2005.

There are over Ioo work-environment questions in the AMU. The items included in the analyses in this study have been chosen against the background of findings from previous research on the link between 
threats and violence and other conditions at work. Regression analyses have been used to identify 'violence-related working conditions' in the AMU between I995 and 2005. The results of these analyses are not presented here, since they are extensive and in fact merely constitute a (necessary) interim step on the path to our central analyses (a detailed review of all this is presented in Jerre 2009). Our primary interest here is in trends in violence-related working conditions as reflected in the AMU between I99I and 2005.

\section{Altered exposure to violence-related working conditions?}

According to the AMU data, exposure to work-related violence has increased during I995-2005. The increase is somewhat more marked among women (from $16 \%$ to $19 \%$ ) than among men (from $8 \%$ to $9 \%)$. The less marked nature of the increase by comparison with the ULF data presented in Study I above is explained at least in part by the fact that the AMU cannot capture that part of the increase that occurred prior to the second half of the I990s. This limitation does not extend to the ability of the AMU to follow trends in violence-related working conditions. How then have these evolved over time?

To begin with, it can be noted that the proportion exposed to violence-related working conditions is higher among women than among men (Appendix, Table A). As regards trends in risk factors, the data show that the proportions who report working under negative stress and who work evenings, nights or in shifts have increased among both women and men. The extent of other violence-related working conditions has not increased over time, however. It is reasonable to assume that the proportion exposed to violence is higher among those who are simultaneously exposed to several violence-related working conditions. This is also what emerges from the analysis of the AMU data (see Jerre 2009). The proportion of women exposed to high levels of violence-related working conditions has increased during the period that has witnessed increases in exposure to threats and violence (Figure 3 ). The proportion of men exposed to violencerelated working conditions has remained stable, however (as a result of changes in the questionnaire, the effects of an accumulation of risk factors cannot be examined all the way to 2005; see Appendix, Table A).

\section{Differences between sexes and occupations} Against the background of the sex differences in victimization, and of the sex segregation that exists in the labour market, it is of interest to analyse trends in exposure to threats and violence, and to violencerelated working conditions, in different occupational groups. Firstly, the AMU data show that exposure to threats and violence is

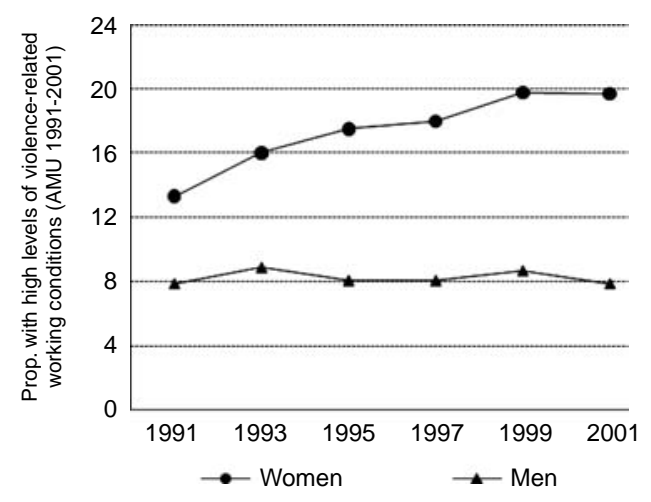

Figure 3. Trends in proportion (per cent) of women and men exposed to high levels of violence-related working conditions according to AMU 1991-2001. 
the same for men and women within each occupational group. This corresponds to the results of the victim survey presented in Study I. Has the proportion exposed to high levels of violence-related working conditions increased, then, in the different occupational groups? Our analysis of the AMU shows that in the categories Social services and welfare and, to a lesser extent, health care, there is some increase during the I990s in the proportion with high levels of exposure to violence-related working conditions. There is an increase subsequent to I995 among those working in the schools sector. For the remainder, this proportion remained relatively stable between I99I and 200I.

\section{Correlation between exposure to violence} and violence-related working conditions Are there, then, any signs that the increase in exposure to threats and violence at work is related to an increase in exposure to violence-related working conditions?
Figure 4 (A and B) describes the relationship between the proportion exposed to threats and violence and the proportion exposed to violence-related working conditions. If the two co-vary, the plots in each group would take the form of a straight line rising to the right of the diagrams (the higher the level of exposure to violence-related conditions, the higher the level of exposure to violence). Figure $4 \mathrm{~A}$ shows that this is more prominent for women than for men. Focusing instead on the various occupational groups, it is only in the social services and welfare category that increased exposure to threats and violence is correlated with increased exposure to poor working conditions (Figure $4 \mathrm{~B})$.

\section{Conclusion: working environment and exposure to violence}

The results in this section indicate that periods of increased violence co-vary at
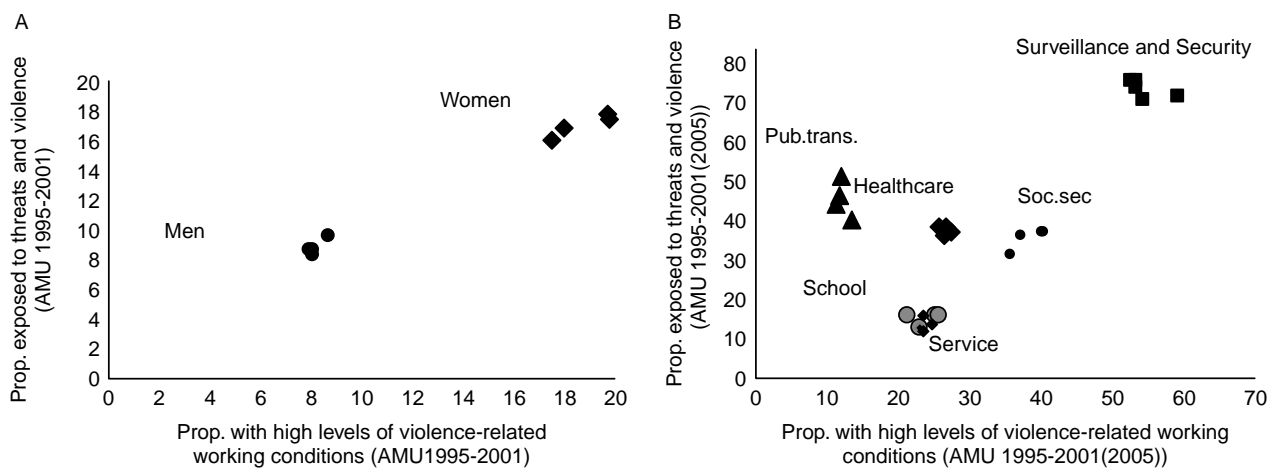

Figure 4. Covariation between proportions (per cent) exposed to threats and violence and proportion with high level of exposure to violence-related working conditions. Men and women (4A) and occupational groups (4B). AMU 1995-2005. Note: Figure 4 illustrates the relationship between the independent variable (exposure to violence-related working conditions) on the $x$-axis and the dependent variable (exposure of threats and violence) on the $y$-axis. The position each dot takes in the co-ordinate system is decided by the proportion exposed to violence-related working conditions and the proportion exposed to violence in a certain year. It is the pattern of the plots within each cluster that is the most interesting to study. If high values on the independent variable systematically yield high values on the dependent variable the plots within each cluster forms a straight line up to the right. This pattern is more visible among women than men (Figure $4 A$ ) and among those working in the social services (Figure 4B). 
least to some extent with periods of increased exposure to those working conditions that appear to be related to violence exposure. This correlation is primarily found among women, however. The proportion exposed to high levels of risk-related working conditions has increased among women but not among men, and in female-dominated but not male-dominated occupations. By contrast with what would be expected if the difference between men's and women's exposure was exclusively work-related, however, the correlation between violence and exposure to violence-related working conditions is generally not more pronounced within the occupations dominated by women as compared with those dominated by men (Figure ${ }_{4} \mathrm{~B}$ ). With regard to the covariation between threats and violence and exposure to violencerelated working conditions, then, the differences between women and men appear in part to be linked to gender itself. This result means that there is good reason, not least for the purposes of prevention, to apply a gendered perspective in future studies of the role played by the working environment and by changes in this environment, in employees' risks for exposure to threats and violence.

Altogether this study shows that deteriorating working conditions play a certain role in trends in work-related threats and violence. It is clear, however, that changes in working conditions alone cannot explain the registered trends in violence at work. The question thus remains as to whether there has also been a shift in perceptions as to what should be regarded as an incident of threatening behaviour/violence at work. The third study presented in this article therefore examines shifts in the amount of attention focused on this problem since the end of the I970s.

\section{Study 3: Violence at work in trade union journals 1978-2004}

Shifts in what is perceived to constitute an act of violence, the amount of attention focused on violence, and the prevailing reporting routines all affect how much violence is recorded in official statistics. This is clear, for example, from Estrada's (200I) study of trends in youth crime, which shows that the view of what constitutes a 'reportable' violent incident has become broader. The objective of this study is to describe the trend in the amount of attention focused on work-related violence in the trade press during the period I978-2004. The main questions addressed are: How much do the journals write about work-related threats and violence? What types of incidents are described? The focus is directed primarily at the issue of a possible shift in the conceptualization of violence.

\section{Material}

The study focuses on six journals. The journals have a large national circulation. Journals were chosen whose readership encompasses a broad range of occupations. The material covers six different sectors: school, retail, health care, social services, security, and other. Five of the categories comprise occupations that previous research (see above) has shown to be high-risk sectors for exposure to threats or violence. By starting in the I970s, the period sampled covers the years when victimization started to increase according to victim surveys.

The analysis has included the front and rear cover pages and the inside pages 
referred to on these, editorials, and the first two pages that include news articles. The systematic nature of this approach allows for comparability over time, despite differences between the journals. The analytical point of departure has been quantitative content analysis. The strength of this method lies in its ability to create an overview of a large data set and to provide a basis for comparisons. The material has been coded using a detailed code-book (Wikman 2008) and focuses on what is expressed explicitly in a given article. Intersubjectivity tests have been conducted, and the level of correspondence was no lower than $87 \%$ for any of the coded variables.

Four different categories are employed to describe the various types of violence covered by the articles on work-related violence: Intruder violence, client-related violence, relational violence, and structural violence. These categories are conspicuous in current research (see e.g. Budd 200I; Bowie 2002; Catley 2005; Waddington 2005; Tombs 2007). The type of violence traditionally of interest to criminologists and the justice system is intruder violence. One occupational group that is often linked to this type of victimization are those who handle money in some way, such as bank employees or check-out staff.

Client-related violence includes aggressive acts by consumers, clients, patients, or their relatives and is often directed at staff in the welfare sectors or others who work with service provision. One sub-category of this type of violence covers the violence directed by staff at e.g. patients. The use of excessive force by security staff and police is also included in this category. Relational violence involves a perpetrator who is acquainted with the victim. This most commonly relates to bullying and sexual harassment between employees at the same work-place. The responsibility for structural violence lies with organizations or employers and the culture around which the work is based. This may for example relate to traditions of bullying or the systematic harassment of certain groups within certain institutions. It may also relate to organizations that expose their employees or clients to situations associated with risks to their lives or health without making them aware of this or taking precautions to protect them, e.g. by allowing them to work in unhealthy environments or by selling dangerous pharmaceuticals or food-stuffs. Criminologists have traditionally shown little interest in this type of violence (Mayhew 2002). According to Tombs (2007), this is linked to the fact that criminological research tends to focus on a pathological model which traditionally views clients, patients, etc., as responsible for violence. The responsibility of firms and organizations thus becomes less visible.

\section{The depiction of work-related violence in trade journals}

The sample included 402 articles on threats or violence. Up until the beginning of the I990s, approximately the same numbers of articles were written about threats or violence each year (Figure 5). At the end of the period, however, there are more than five times as many articles than there were at the beginning. The increase is distributed across different types of violent crime, with the exception of the most serious offences (rape and murder) which do not increase at all. Thus the trend cannot be understood as a result of a new type of crime having emerged. 


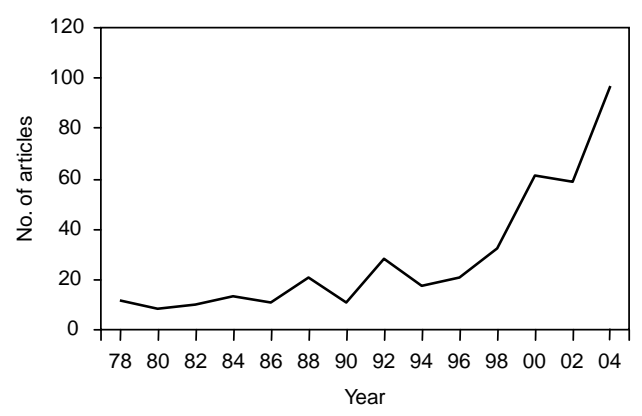

Figure 5. Number of articles on violence or threats during the period 1978-2004 $(n=402)$.

\section{Which occupations are exposed to the violence?}

As has been noted, one of the explanations for the increase in work-related violence is that more women working in welfare occupations have reported being exposed to violence. An interesting question in this context is therefore that of which occupational groups are described as being exposed to violence and whether this has changed over time.

As can be seen from Figure 6, retail is the dominant sector described in the articles

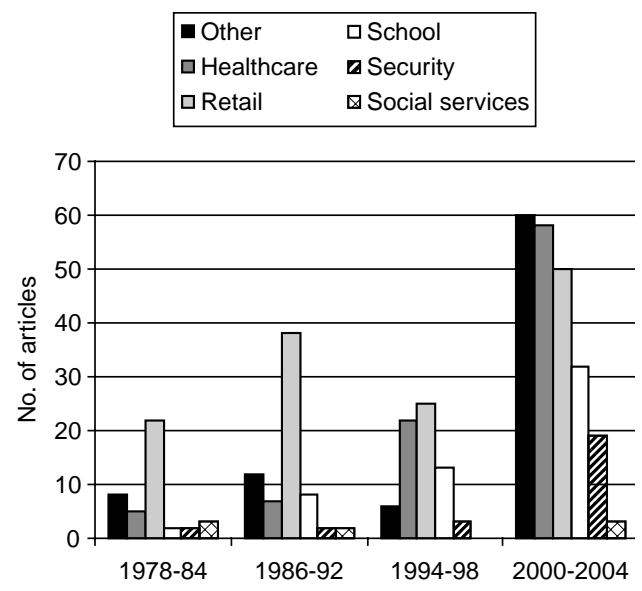

Figure 6. Frequency of different sectors in number of articles by period $(n=402)$. until the mid-I990s. Over half of the articles relate to violence (most commonly robberies) within this occupational group. From 1994, however, the dominance of this traditional type of violence is challenged by articles that describe incidents that have occurred in the bealth care sector. Following the turn of the millennium, the majority of articles relate to the bealth care sector or to violence occurring in the other occupations category. The latter is dominated during the period 2000-2004 by articles that describe threats and violence against politicians, which became the focus of a great deal of attention following the murder of Anna Lindh, Sweden's Foreign Minister, in 2003.

Approximately one-third of the articles focused on the health care sector describe violence perpetrated by staff against clients. It is thus common for health care staff to be described in the material as perpetrators. Many of these articles relate to groups of staff who are concerned over what they perceive to be an increased reporting propensity. Security and social service occupations are described relatively rarely in this material, particularly by comparison with victim surveys, in which they are among the most victimized occupational groups. The situation is the reverse as regards politicians and the school sector. These are often portrayed in the journals as arenas for victimization.

By the end of the period examined, the character of the typical depiction of workrelated violence has changed (Table 4). Up until the beginning of the rg9os intruder violence was the focus of almost half of the articles that the trade press devoted to work-related violence. Even if the number of such articles increases over time, the proportion of the total that they 
Table 4. Proportion (per cent) of articles depicting different types of violence, 1978-2004 $(n=38 I)$.

\begin{tabular}{|c|c|c|c|c|c|}
\hline Type of violence & $\begin{array}{l}\text { I978-84 } \\
(n=42)\end{array}$ & $\begin{array}{l}\text { I986-92 } \\
(n=68)\end{array}$ & $\begin{array}{c}\text { I994-98 } \\
(n=68)\end{array}$ & $\begin{array}{l}2000-04 \\
(n=203)\end{array}$ & $\begin{array}{c}\mathrm{I} 978-2004 \\
(n=38 \mathrm{I})\end{array}$ \\
\hline Intruder violence $(n=\mathrm{I} 20)$ & 45 & $4 \mathrm{I}$ & 34 & 25 & 32 \\
\hline Client-related violence $(n=\mathrm{I05})$ & 38 & $2 \mathrm{I}$ & I9 & $3 \mathrm{I}$ & 28 \\
\hline Violence by staff $(n=55)$ & IO & 9 & I 8 & I 6 & I4 \\
\hline Relational violence $(n=39)$ & 2 & $\mathrm{I} 3$ & I9 & 8 & IO \\
\hline Structural violence $(n=62)$ & 5 & I6 & IO & $2 \mathrm{I}$ & I6 \\
\hline
\end{tabular}

account for decreases markedly, and by the beginning of the 2000 s the most commonly depicted category is instead client-related violence.

The trend in the type of violence given the least attention in criminological research (see Tombs 2007) is also notable. From having devoted hardly any attention to structural violence, following the millennium we find that the trade press focuses on this type of violence in one-fifth of the articles. What, then, does structural violence involve? Since the definition of this type of violence (see above) means that it is often of an anonymous character, it is no surprise that the occupation/sector involved is not even mentioned in a quarter of these articles. In those articles where structural violence is linked to specific work-places, these are sometimes in the health care and retail sectors, but it is most commonly building and installation workers that are described as victims.

Bowie (2002) argues that structural violence may be linked to and affect the other categories. If, for example, there is a poor climate at the work-place, this would also increase the risk for the occurrence of other categories of violence. Employees who state that they are under stress, burnt out, and exhausted, etc. are also exposed to violence to a greater extent (see Study 2 above). It is therefore the case that many of the articles on structural violence reflect ambivalence as regards whether the incident in question should be viewed as a crime or as a more general work-environment problem. The descriptions of structural violence thus contain signs of doubt in relation to the questions of culpability and intent. The authors simply do not know whether the incident should be defined as criminal violence or as an accident where nobody should be held responsible.

\section{Conclusion: analysis of the trade press}

One conclusion that can be drawn from this third study is that the amount of attention focused on work-related violence remained relatively constant between $\mathrm{I} 978$ and 1998 and then increased markedly, first and foremost following the turn of the millennium. This suggests that the attention focused on work-related violence by the trade and employers' press was of a 'reactive' character, as was also the case in Estrada's (200I) study of teaching journals' descriptions of violence in school. Thus the trade press chose to write about violence at work only once violence had already become established as a high-profile social problem. 
The increase in the level of attention focused on work-related violence is primarily associated with an expansion of the types of incident focused on by the trade press. An increasing number of articles focus on threats and violence in the femaledominated health care sector, against politicians, and on structural violence primarily against men. Although Tombs's (2007) observation that work-related violence finds it difficult to attract the attention of politicians, the media, and even criminologists seems reasonable, it is clear that, at least in Sweden, interest has increased in the use of an expanded view of what should be regarded as constituting work-related violence.

It is also notable that the sex segregation that characterizes the labour market is reflected in marked differences in the type of violence that affects different occupational sectors. Given that there are differences in men's and women's perceptions of what constitutes violence and how it should be dealt with (e.g. Stanko I990), it would be fruitful to analyse typical male and female work-places and the significance of these environments for views on violence. An article based on this same material is currently in preparation which will focus on differences in how different actors view the causes of the problem, and on which counter-measures they propose.

\section{The emergence of work-related violence as a social problem-a discussion}

In this article we have approached the issue of trends in work-related violence on the basis of different data sets and analytical methods. Our choice of studies has been based on two of the most common explanations for why work-related violence appears to have increased over recent decades. The one explains the apparent increase by reference to changes in working conditions, which have increased employees' risk of victimization; the other by reference to a broadened view of what it is that is regarded as violence at work and to an increase in the level of attention focused on this issue. The research project has proceeded from a theoretical understanding that the extent of and trends in complex social problems may be linked both to actual shifts in underlying conditions (the objectivist explanation), and to shifting perceptions as to the nature of the problem and how it should be dealt with (the constructionist explanation). The study of these two explanations requires analyses of different types of data, which is what we have presented in this article.

We have found support for both major explanations of the increase in workrelated violence. We have shown that the increase in victimization reflected in victim surveys is primarily due to the victimization trend among women working in the health care and welfare occupations. Our analysis of work environment surveys shows that women also report that they are more often exposed to working conditions that are associated with a higher risk for violence. So far, then, the hypothesis on a link between a deterioration in working conditions and increased exposure to violence holds. The existence of periods when high exposure to violence is not reflected in higher proportions reporting exposure to violence-related working conditions constitutes a problem for this explanation, however. Such periods are found for more or less all of the different occupational groups analysed and most clearly among men. It is therefore likely that changes in working conditions 
cannot by themselves serve to explain the trends in registered exposure to workrelated violence. It is also important that explanations attend to the shift in the level of attention focused on violence at work.

Our results show that this has increased and that, during the period examined, work-related violence has become much more than 'simply' robberies of banks and shops. The traditional image of the rational criminal is being challenged by the depiction of new violent perpetrators such as persons suffering from senile dementia, and nurses and businesses. Thus the shift relates not only to a broadening definition of which incidents may be regarded as constituting violence but also to a focus on new groups of victims and perpetrators. We have shown that working conditions in welfare occupations in particular have started being described as involving a risk for violence to a much greater extent. It is reasonable to conclude that this shift in perceptions of work-related violence has had an effect on the problem's visibility in various types of statistical data, including those collected in victim surveys.

In summary, both explanations appear reasonable, and both find support in our data. We would therefore argue that rather than being viewed as conflicting with one another, the explanations may be seen as complementary in relation to our understanding of why more individuals are reporting exposure to work-related violence. The different dimensions we have studied (increased reporting propensities, expanded definitions, and a reduced tolerance for violence, as well as changes in working conditions) are interrelated. In short, we would argue that the data presented in this article provide support for an explanation that refers both to a tougher working environment and an increased sensitivity to violence. From the perspective of the working environment, it is reasonable to imagine that increased exposure to unfavourable working conditions will reduce levels of tolerance for additional stressors such as threats and violence in the work environment. This reduced tolerance could lead to an increase in the propensity to report threats and violence in those occupational groups that have experienced this kind of trend in relation to their working conditions. With an increasing level of sensitivity to violence, in part as a result of increased exposure to negative working conditions, it is further plausible that a wider range of incidents than previously are perceived as violations or as unwarranted violence. If this represents a correct reflection of the actual chain of events, we should expect a trend whereby incidents involving conflicts that had previously been viewed as merely part of the job, increasingly come to be perceived as work-related violence. In the end, such a trend would lead to such incidents also being reported and to their becoming more visible in victim surveys. The more detailed workings of this process, and the consequences of these trends for the measures that should be advocated both to prevent violence and improve working conditions, present an important challenge to the research community.

\section{Acknowledgements}

The article was written in the framework of the FAS (Swedish Council for Working Life and Social Research)-financed project 'Violence at work-the emergence, development and structure of a social problem'. We would like to thank David Shannon for translating the text. 


\section{References}

Bäckman O (200I). Med välfärdsstaten som arbetsgivare—arbetsmiljön och dess konsekvenser inom välfärdstjänsteområdet på I990-talet [Employed by the Welfare State: The Working Environment and its Consequences in the Welfare Service Sector in the I990s]. In: Szehelby M (ed.). SOU 200I:52. Välfärdstjänster i omvandling [Welfare Services in Transition]. Forskarantologi. Kommittén välfärdsbokslut. Stockholm: Fritzes.

Balvig F, Kyvsgaard B (2006). Volden i Danmark I995 og 2005 [Violence in Denmark I995 and 2005]. Københavns Universitet, Justitsministeriet, Det Kriminalpræventive Råd, Rigspolitichefen. Available at: http://www.dkr.dk/ftp_files/ WEBDOX/PDF/dkr_mat_I06.pdf (accessed 3 April 2007).

Best J (1993). But seriously folks: The limitations of the strict constructionist interpretation of social problems. In: Holstein JA, Miller G (eds). Reconsidering Social Constructionism. pp. I29-I 50. New York: Aldine de Gruyter.

Best J (I995). Constructionism in Context. In: Best J (ed.). Images of Issues: Typifying Contemporary Social Problems.

pp. 337-354. New York: Aldine de Gruyter.

Blumer H (I97I). Social Problems as Collective Behaviour. Social Problems I 8:298-306.

Bowie V (2002). Defining violence at work: a new typology. In: Gill M, Fisher B, Bowie V (eds). Violence at Work. Causes, Patterns and Prevention. Devon: Willan Publishing.

Brink O, Mathiesen Bech C (2003). Voldens udbredeise. In: Det Kriminalpreventive Råd (Ed.). Vold på arbejdspladsen. En håndbog om forebyggelse. Scanprint as, Glostrup, Danmark.
Budd T (200I). Violence at Work: New

Findings from the 2000 British Crime Survey. London: Home Office.

Catley B (2005). Workplace Violence and the Forging of Management and Organization History. Paper presented at the Management and Organization History Stream, 4th International Critical Management Studies Conference. Judge Institute of Management, University of Cambridge, UK, 4-6 July 2005 .

Chappell D, Di Martino V (2006). Violence at Work. Genève: International Labour Office.

Christiansen JM (2005). Vold på arbejdet—med særlig vægt på FTF-medlemmers arbejdspladser [Violence at work]. Copenhagen: CASA.

Engelstad F (2003). Makt og demokrati i arbeidslivet [Power and Democracy in Work Life]. Oslo: Gyldendal Norsk Forlag.

Estrada F (200I). Juvenile Violence as a Social Problem. Trends, Media Attention and Societal Response. British Journal of Criminology 4I:639-655.

Estrada F (2006). Trends in Violence in Scandinavia According to Different Indicators. British Journal of Criminology 46:486-504.

Estrada F, Nilsson A, Wikman S (2007). Det ökade våldet i arbetslivet. En analys utifrån de svenska offerundersökningarna [The Increase in Work-Related Violence. An Analysis Based on Swedish Victim Surveys]. Nordisk Tidsskrift for Kriminalvidenskab 94: 56-73.

EWCO (2007). Violence, Harassment and Discrimination in the Workplace. In: Fourth European Working conditions Survey. Available at: http://www.eurofound.europa.eu (accessed 26 April 2007).

Findorff MJ, McGovern P, Wall M, Gerberich S, Alexander B (2004). Risk Factors for Work Related Violence in a Health Care 
Organization. Injury Prevention I0:296-302.

Flannery RB (1996). Violence in the Workplace, I970-I995: A Review of the Literature. Aggression and Violent Behaviour I:57-68.

Gage M, Kingdom D (1995). Breaking the Cycle of Aggression. Journal of Nursing Administration 25:5 5-64.

Heiskanen M (2007). Violence at Work in Finland; Trends, Contents, and Prevention. Journal of Scandinavian Studies in Criminology and Crime Prevention 8:22-40.

Hurrell JJ, Worthington KA, Driscoll RJ (I997). Job stress, gender and workplace violence: Analysis of assault experiences of state employees. In: VandenBos GR, Bulatao EQ (eds). Violence on the Job. Washington DC: American Psychological Association.

Jerre K (2009). Ökat hot och våld i arbetsliveten följd av förändrade arbetsförhållanden? En studie utifrån de svenska Arbetsmiljöundersökningarna I99I-2005 [Increase in Work-Related Violence. A Reflection of Changes in Working Conditions? An Analysis Based on the Swedish Work Environment Surveys]. Sociologisk Forskning I:67-89.

Karasek R, Theorell T (I990). Healthy Work: Stress, Productivity and Reconstruction of Working Life. New York: Basic Books.

Kitsuse JI, Cicourel A (I963). A Note on the Uses of Official Statistics. Social Problems II:I3I-I39.

Kop N, Euwema M, Schaufeli W (I999). Burnout, Job Stress and Violent Behaviour among Dutch Police Officers. Work \& Stress I3:326-340.

\section{Kruize P, Sorensen DWM, Dreyer Lassen D} (2008). Vold mod offentligt ansatte [Violence against Employees in the Public Sector]. Odense: Syddansk Universitetsforlag, Rockwool Fonden.
Lindgren SÅ (2005). Social Constructionism and Criminology: Traditions, Problems and Possibilities. Journal of Scandinavian Studies in Criminology and Crime Prevention 6:4-22.

Mayhew C (2000). Preventing Client-Initiated Violence: A Practical Handbook. Australian Institute on Criminology Research and Public Policy Series No. 30. Canberra.

Mayhew C (2002). Occupational violence in industrialized countries: types, incidence patterns and 'at risk' groups of workers. In: Gill M, Fisher B, Bowie V (eds). Violence at Work: Causes, Patterns and Prevention. Cullompton: Willan.

Menckel E, Viitasara E (2002). Threats and Violence in Swedish Care And WelfareMagnitude of the Problem and Impact in Municipal Personnel. Scandinavian Journal of Caring 16:376-385.

Nilsson A, Estrada F (2003). Victimisation, Inequality and Welfare during an Economic Recession. A Study of Self Reported Victimisation in Sweden 1988-1999. British Journal of Criminology 43:655-672.

Poster EC (1996). A Multinational Study of Psychiatric Nursing Staff's Beliefs and Concerns about Work Safety and Patient Assault. Archives of Psychiatric Nursing IO:365-373.

Stanko E ( I990). Everyday Violence: How Women and Men Experience Sexual and Physical Danger. London: Winchester.

Steffensmeier D, Schwartz J, Zhong H, Ackerman (2005). An Assessment of Recent Trends in Girls' Violence Using Diverse Longitudinal Sources: Is the Gender Gap Closing? Criminology 43:355-406.

Tombs S (2007). Violence, Safety Crimes and Criminology. British Journal of Criminology 47:53I-55O.

Viitasara E, Menckel E (2002). Developing a Framework for Identifying Individual and 
Organizational Risk Factors for the Prevention of Violence in the Health-Care Sector. Work I9:II7-I23.

Viitasara E, Sverke M, Menckel E (2003). Multiple Risk Factors for Violence to Seven Occupational Groups in the Swedish Caring Sector. Industrial Relations 58:202-23I.

Waddington P, Badger D, Bull R (2005). Appraising the Inclusive Definition of Workplace Violence. British Journal of Criminology 45:I4I-I64.

Wikman S (2008). Våld på jobbet. Beskrivningar av våld i arbetslivet I978-2004 i facklig press [Violence at work. A study of the media coverage on workplace violence in Swedish trade union journals I978-2004]. Sociologisk Forskning 3:6-3 I.

FELIPE ESTRADA

Department of Criminology Stockholm University I06 9I Stockholm SWEDEN

Email: felipe.estrada@criminology.su.se 


\section{Appendix}

Table A. Trend in proportion (per cent) who according to the AMU I99I-2005 have reported violence-related working conditions, by sex.

\begin{tabular}{|c|c|c|c|c|c|c|c|c|}
\hline & I99I & 1993 & I995 & I997 & I999 & $200 \mathrm{I}$ & 2003 & 2005 \\
\hline \multicolumn{9}{|c|}{ Contact with sick people or people with problems } \\
\hline Total & 33 & 35 & 33 & 33 & 34 & 34 & 35 & 36 \\
\hline Women & 42 & 46 & 45 & 45 & 45 & 46 & 47 & 48 \\
\hline Men & 23 & 24 & 22 & 20 & $2 I$ & $2 I$ & 22 & 23 \\
\hline \multicolumn{9}{|c|}{ Contact with clients } \\
\hline Total & 83 & 84 & 82 & 82 & 82 & 83 & & 85 \\
\hline Women & 84 & 86 & 85 & 85 & 86 & 87 & & 88 \\
\hline Men & $8 \mathrm{I}$ & 82 & 78 & 79 & 78 & 80 & & 82 \\
\hline \multicolumn{9}{|c|}{ Working night-shifts } \\
\hline Total & I3 & I 6 & I9 & I 8 & 20 & 20 & I 8 & \\
\hline Women & I 5 & 20 & 23 & 22 & 23 & 23 & $2 \mathrm{I}$ & \\
\hline Men & I I & $\mathrm{I} 2$ & I 5 & I 5 & I7 & I 6 & I 6 & \\
\hline \multicolumn{9}{|c|}{ Working alone (in critical situations) } \\
\hline Total & 79 & $8 \mathrm{I}$ & $7 \mathrm{I}$ & 70 & 73 & 73 & & 75 \\
\hline Women & 72 & 75 & 66 & 64 & 68 & 69 & & 70 \\
\hline Men & 86 & 87 & 77 & 76 & 78 & 77 & & 80 \\
\hline \multicolumn{9}{|c|}{ High strain/stress } \\
\hline Total & 20 & 22 & 24 & 28 & 30 & 27 & 25 & 28 \\
\hline Women & 25 & 27 & 29 & 34 & 36 & 33 & $3 I$ & 34 \\
\hline Men & I 5 & I 8 & I9 & 22 & 23 & $2 I$ & I9 & 22 \\
\hline \multicolumn{9}{|l|}{ Lighting } \\
\hline Total & $3 I$ & $3 I$ & 29 & 30 & 32 & 34 & 34 & 33 \\
\hline Women & 22 & 22 & $2 I$ & 22 & 24 & 26 & 26 & 25 \\
\hline Men & 40 & $4 \mathrm{I}$ & 38 & 38 & $4 \mathrm{I}$ & 43 & 43 & $4 \mathrm{I}$ \\
\hline
\end{tabular}

